\title{
Analysis of The Potential Impact of Regional Comprehensive Economic Partnership on
} the ASEAN Member Countries

\author{
Makmun Syadullah ${ }^{1 *}$, Miftahudin ${ }^{1}$, Benny Gunawan Ardiansyah ${ }^{2}$ \\ ${ }^{1}$ Fiscal Policy Agency, the Ministry of Finance of the Republic Indonesia \\ ${ }^{2}$ State Finance College, the Ministry of Finance of the Republic of Indonesia \\ *makmunsyadullah@yahoo.com,miftahudin_depkeu@yahoo.com, bennygunawan.ardiansyah@gmail.com
}

\begin{abstract}
This paper aims to analyze the potential impacts of the RCEP concept developed in the working group and the potential impact on market expansion. Based on the results achieved in the working group discussions, we used a qualitative approach. We put together a simulation of how the impact on trade and market development has been the goal of the establishment of RCEP. We concluded that the unification of the 16 countries in the RCEP expected to reduce the spaghetti bowl effect caused by a number of free trade agreements followed by a country. However, because RCEP does not eliminate regional free trade agreements that exist, RCEP tend to add to the chain's new spaghetti bowl. In addition, the opening of market access among partner countries in the ASEAN-expected results in increased trade intra-ASEAN partner countries so that the impact on economic growth in the region in general and ASEAN in particular.
\end{abstract}

Keyworld: RCEP, RCA dynamic, competitiveness, trade, export-import

\section{Introduction}

RCEP formation initiatives coming from Indonesia. The initiative has been made based on the response of ASEAN to maintain ASEAN centrality of the Chinese proposal regarding the establishment of the East Asia Free Trade Agreement (ASEAN + 3) and the Japanese proposal that wants Closer Economic Partnership in East Asia (ASEAN + 6) and the level of liberalization of trade in goods on trade cooperation ASEAN free (ATIGA) and ASEAN + 1 (AANZFTA, ACFTA, AIFTA, AJCEP, AKFTA) average about 90\%. Thus to optimize trafficking in the region need to be made of the free trade agreements in the region. However, RCEP not negate free trade agreement ASEAN free trade (ATIGA) and ASEAN + 1 (AANZFTA, ACFTA, AIFTA, AJCEP, AKFTA) said existing. The RCEP concept was initially endorsed by ASEAN leaders in November 2011. At ASEAN's invitation officials from Australia and ASEAN's five other FTA partners - China, India, Japan, ROK and New Zealand - participated in preparatory discussions in the latter half of 2012 to develop Guiding Principles and Objectives for Negotiating the RCEP, which were considered by ministers in August 2012. At the 7th East Asia Summit on 20, November 2012, then Prime Minister Julia Gillard and then Minister for Trade and Competitiveness Dr. Emerson joined Leaders from ASEAN and ASEAN's FTA partners to officially launch the RCEP negotiations.

RCEP is a combined formula of ASEAN+3 in the East Asian Free Trade Area (EAFTA) and ASEAN+6 in the CHAPA (Comprehensive Economic Partnership in East Asia). The initiators of the RCEP concept were China and Japan that dominated the two forms of the formulas. However, the RCEP lengthen the list of issues in the free trade agreements in Asia, known as "noodle bowl of Asian trade agreements". While the objective of the partnership would expand ASEAN's role in coordinating regional trade, the RCEP's key purpose is to reconcile two long-standing proposals into a large region-wide trade agreement: the East Asian Free Trade Agreement, which included ASEAN, China, Japan and South Korea, and the Comprehensive Economic Partnership, which added Australia, India and New Zealand. The RCEP bridges the two proposals by adopting an open accession scheme. Negotiations among the 16 parties began in early 2013 and are scheduled to conclude by the end of 2015. Pomfret and Pontines (2013a) show that in various gravity model specifications, bilateral export is positively associated with the level of depreciation of the exchange rate and membership in regional trading arrangement (RTA), and negatively impact the volatility of exchange rates. This indicates that both effects of the exchange rates are larger when the two countries have trade agreements. This research was conducted at 16 East Asian countries (ASEAN+3, Hong Kong, China; Macau and Mongolia) in the period 1990-2010.

The above results are supported by Kawai and Vighnaraja (2013a) who show that a well-designed FTA can provide benefits. This is reflected in the significant expansion exports in South Korea, Thailand, Viet Nam, and Malaysia. Exports of the Republic of Korea in the period of 2008-2011 grew by 49\%, and exports of Thailand 
grew by $42 \%$. Viet Nam and Malaysia also enjoy the sam benefits but on a lower scale. Vietnam and Malaysia export increase by $33 \%$ and $24 \%$, respectively. A company survey conducted by Kawai and Vighnaraja (2013b) in mainland China, Japan, Republic of Korea, Malaysia, the Philippines, Singapore, and Thailand also shows the approximate use of FTA by companies at a higher level. About $32 \%$ of companies have leveraged the FTA and have created a better plan to do it. The survey also revealed that the FTA requires a relatively fixed cost. Big companies are more able to collect financial and human resources than small and medium enterprises (SMEs). RCEP is expected to be a high-quality and beneficial economic partnership agreement, aiming to broaden and deepen the current FTA engagements. Since the RCEP negotiating members already have an FTA structure in place the main goal will be to integrate these FTAs into a regional economic framework. RCEP is expected to be a high-quality and beneficial economic partnership agreement, aiming to broaden and deepen the current FTA engagements. Since the RCEP negotiating members already have an FTA structure in place the main goal will be to integrate these FTAs into a regional economic framework (Çelikkol, 2013). The RCEP negotiation framework can give ASEAN a source of additional bargaining power toward a higher target which is not valid under bilateral negotiations (Fukunaga and Isono, 2013). Through the RCEP is expected to create an integrated market which covers more than 3.3 billion population with gross domestic product (GDP) combined share of more than $\$ 19.7$ trillion. Thus, it can be controlled almost 50 percent of global trade.

The RCEP faces some key challenges if it is to live up to its potential. Based on RCEP's Guiding Principles is that it will add to, rather than replace, existing ASEAN+1 FTAs, while at the same time introducing 'significant improvements' over these agreements. There is, however, an important qualifier in the dreaded 'flexibility' clause: 'RCEP will include appropriate forms of flexibility including provision for special and differential treatment, plus the additional flexibility to the least-developed ASEAN Member States'. On the one hand, RCEP trying to achieve a modern and comprehensive trade agreement among members. The negotiation agenda includes trade in goods and services, investment, economic and technical cooperation and dispute settlement. This cooperation will support the deployment of global production networks, and reduce the inefficiencies of some Asian trade agreements that currently exist. But on the other hand, RCEP will potentially bring different impacts of the ASEAN member countries, because of differences in product preference. This paper aims to analyze the potential impacts of the RCEP concept developed in the working group and the potential Impact on market expansion.

Research Method: The discussion in the Working Group on Trade in Goods (WG-TIG) on RCEP still focuses on the discussion of request and offer. Access to new markets in the RCEP will only be obtained by each of the ASEAN partner countries in other ASEAN partner countries. This led to the RCEP negotiations being essentially negotiations between ASEAN partner countries. Since some partner countries do not yet have free trade cooperation, negotiations are slow. To speed up the negotiations, there is a Basic Concept of Initial Offer (BCIO). The paper was prepared using a qualitative approach. Based on the results achieved in the working group discussions, we put together a simulation of how the impact on trade and market development has been the goal of the establishment of RCEP.

\section{Literature Review}

Generally, RCEP will have a positive impact on economic growth. The impact analysis based on the world CGE model by Ezaki and Nguyen (2007) indicates that the East Asian FTA or East Asian Community generally has positive effects on growth, improves income distribution, and results in poverty reduction, though the impacts on China are a little bit exceptional. The results indicate positive potential or long-run positive effects of the East Asian Community, but its requirement of structural adjustment is the actual problem to be overcome in the short run. Research by Itakura (2013), using GTAP dynamic model for the period 2011-2015, showed the different results. He proved that RCEP will give benefit to all involved countries, except for Laos. Vietnam, Cambodia, and Thailand are the countries, who gain the most benefit with GDP growth about 13,4\%, 9,5\%, and 8,3\% over the baseline. Indonesia will get next rank with GDP growth about 5,8\% (see figure 1). 


\section{Figure 1: The Impact of Free Trade Agreements}

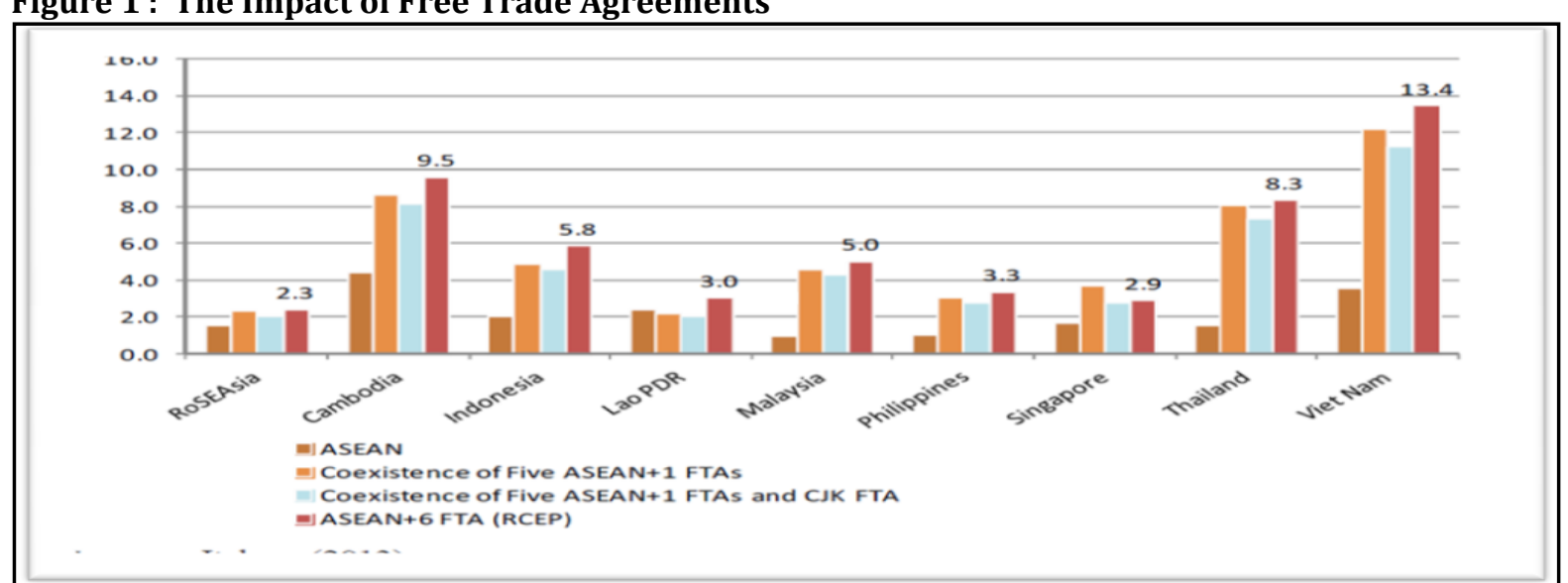

Source: K. Itakura, "Impact of Liberalization and Improved Connectivity and Facilitation in ASEAN for the ASEAN Economic Community", ERIA Discussion Paper 2013-01, 2013

Meanwhile, Heagney (2013) which is viewed from the side of the Lao PDR interest by using the GTAP approach. GTAP estimates indicate that the benefits to Lao PDR from association with the RCEP, on the basis of the liberalization being as wide ranging as possible, are strongly positive. By 2015, GDP growth will be 3\% above the baseline predicted trend path. Welfare will improve $2.49 \%$; exports, imports, and investments are all predicted to increase 5.7\%, 9.1\%. 9.1\% respectively. Ownership of foreign capital does decline but foreign ownership of capital increases; $-1.7 \%$ and $7 \%$ respectively. Indonesia's Government supports the RCEP as the Government believes on its benefits for Indonesia. A large volume of trade within the RCEP is regarded as the opportunity to increase exports and make Indonesia as a production base. It is predicted that RCEP would make the trade balance increases. The size of the ASEAN economy is expected to rise from a USD3 trillion to USD22 billion (Syadullah and Hakim, 2016). By joining with RCEP, Indonesia can improve its welfare. A research by the Ministry of Commerce showed that in 2013, RECP will increase the welfare by USD1.516.3 million. If Indonesia joins the ASEAN+3, its GDP will increase by USD 487.74 million. If Indonesia joins AFTA, its welfare will increase by USD188,05 million.

Trade liberalization is supposed to make the increasing of Indonesia's GDP happen, including the rise of investment and household welfare. For instance, AFTA creates more trade creation than trade diversion. However, Indonesia has the benefit of the trade liberation relatively smaller than other ASEAN countries. The result of simulation for full liberalization of the ASEAN region showed a positive impact on the increase in the volume of Indonesian trade, both exports, and imports. However, the percentage of the import increasing is higher than the percentage of the exports increasing and as the result, it had a negative effect on the trade balance of Indonesia (Syadullah and Ardiansyah, 2014). A company survey conducted by Kawai and Vighnaraja (2013b) in mainland China, Japan, Republic of Korea, Malaysia, the Philippines, Singapore, and Thailand also shows the approximate use of FTA by companies at a higher level. About $32 \%$ of companies have leveraged the FTA and have created a better plan to do it. The survey also revealed that the FTA requires a relatively fixed cost. Big companies are more able to collect financial and human resources than small and medium enterprises (SMEs). Although the FTA has been operating in Asia for more than a decade, the results of empirical studies conducted by Menon (2013) shows that the FTA has no effect on the industrial sector. There are at least three reasons that can be provided. First, most of the tradings have are already been taking place at zero or low tariffs due to The International Technology Agreement. Second, the majority of international trades are unlikely to benefit from concessions in the FTA for the difficulties to comply with rules of origin due to the limitations of adding value. Third, almost all FTAS involving countries of Asia are still constrained by various non-tariff barriers that affect trade flows.

Chiang (2013) explores the economic calculations behind the recent initiatives for the Free Trade Agreement (FTA) between the Governments of China, Japan, and South Korea (CJK) and clarifies the implications for future regional economic integration. One result showed that China active involvement in regional economic integration will push the three countries to go forward towards greater economic cooperation. However, it 
will take longer for China-led RCEP. Therefore, the conclusion of CJK FTA will be an important boost for the further progress of RCEP. It will also be an important stabilizer for the trilateral political relations in the future. Meanwhile, in the Malaysian context, the results Devadason (2014) show that there are indications of commercial ties between China and Malaysia. Both countries should innovate new forms of bilateral cooperation, beyond trade to enhance their strategic partnership. As the potentials to trade between China and Malaysia reduce (or even become exhausted) under the expanded relations of RCEP, the need to inject a fresh momentum in areas such as education, tourism, science, and technology, becomes even more pressing to sustain and balance bilateral cooperation between China and Malaysia. From the Malaysian side, it is even more critical to cultivate ties with China in these diverse areas, as China has many suitors. Further, the asymmetrical investment links between both parties bring to the fore the current gaps in bilateral cooperation. Malaysia's outward investment to China is six times that of the Chinese investments in Malaysia.

\section{RCEP Impact Analysis}

Concept RCEP: The unification of the 16 countries in the RCEP expected to reduce the spaghetti bowl effect caused by a number of free trade agreements followed by a country. However, because RCEP does not eliminate regional free trade agreements that exist, RCEP is likely to add a new chain of spaghetti. Figure 2 shows the flow of additional complexity in regional free trade agreements. In addition, RCEP basically at an increase in new markets in the ASEAN region. The new markets are created only occur between ASEAN partner countries (Australia, China, India, Japan, Korea, and New Zealand) as shown by the increase in the arrow to the right image.

\section{Figure 2: Channel Regional Free Trade Agreements}

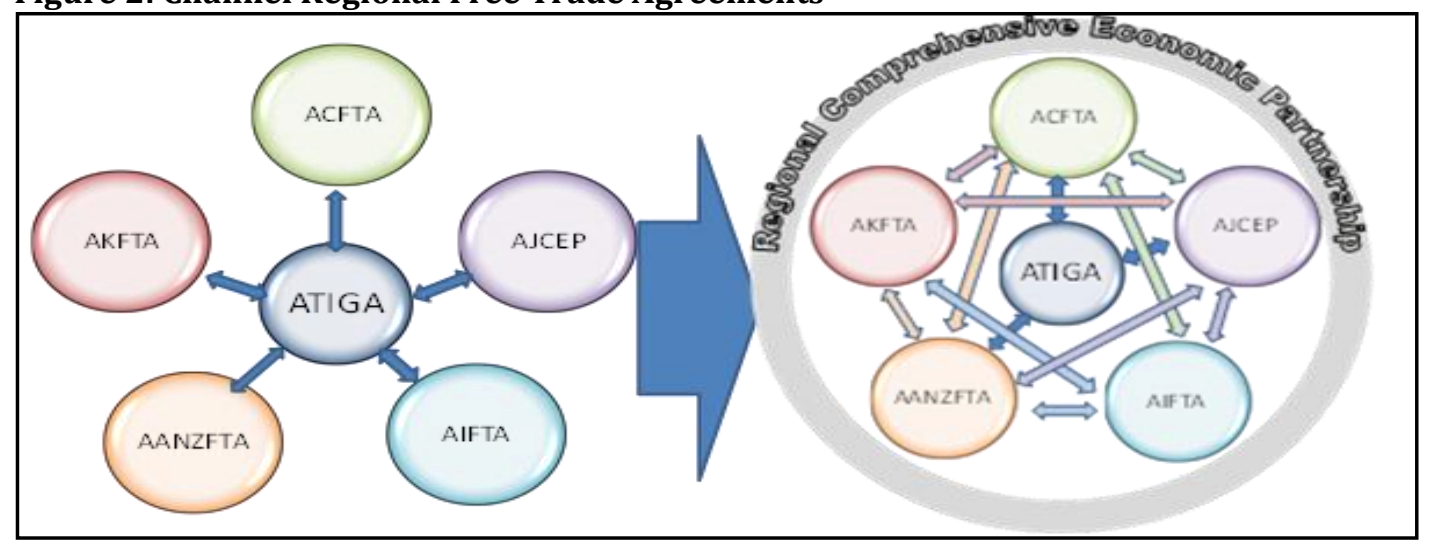

Source: Illustration by author

The opening of market access among ASEAN partner countries is expected to boost intra-ASEAN partner countries thus affect the economic growth of the region in general and ASEAN in particular. Other benefits expected from the merger of 16 countries in the RCEP is their convenience for RCEP member countries to obtain supplies of raw materials. The opening of market access among ASEAN partner countries is expected to boost intra-ASEAN partner countries thus affect the economic growth of the region in general and ASEAN in particular. Other benefits expected from the merger of 16 countries in the RCEP is their convenience for RCEP member countries to obtain supplies of raw materials. In the free trade agreements contained provisions to the criteria of the product as a product so that when the member countries exported to other member states, can obtain preferential tariffs in destination countries. This provision is called Rules of Origin (RO0). One of the provisions of the ROO, namely Regional Value Content (RVC). RVC is a provision regarding the minimum limit of regional content in a product manufactured in a member country. The content can be any regional material content, production costs, and profit from a product. In most of the free regional cooperation trafficking followed by ASEAN, RVC provisions generally is 40\%. RCEP will make it easier for member countries to obtain supplies of raw materials to be accumulated in order to meet all provisions for RVC $40 \%$. Illustrations can be seen in Figure 3. 
Figure 3 : Free Trade Cooperation Scheme difference between the ACFTA and RCEP

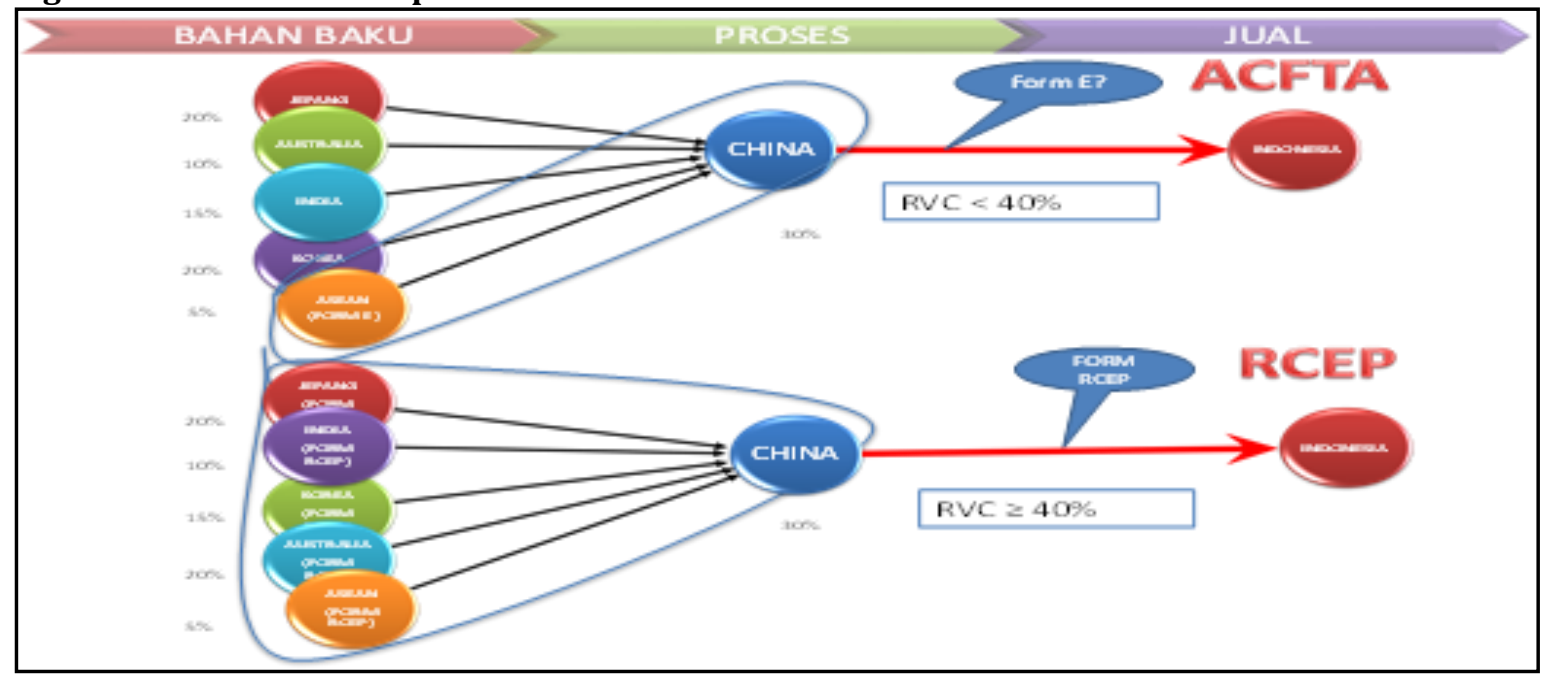

Source: Illustration by author

As an illustration, the image above compares the two schemes, namely free trade agreements and RCEP ACFTA. ACFTA on free trade agreements, regional content that can be taken into account in RVC only raw materials from ASEAN countries and the added value that is happening in China. While in RCEP, regional content can be conducted on all imported raw materials and value-added in China. This is expected to increase intratrade RCEP member countries. As an illustration, the image above compares the two schemes, namely free trade agreements and RCEP ACFTA. ACFTA on free trade agreements, regional content that can be taken into account in RVC only raw materials from ASEAN countries and the added value that is happening in China. While in RCEP, regional content can be conducted on all imported raw materials and value-added in China. This is expected to increase intra-trade RCEP member countries.

\section{Figure 4 : Impact of RCEP on Product Preferences in ASEAN Countries}

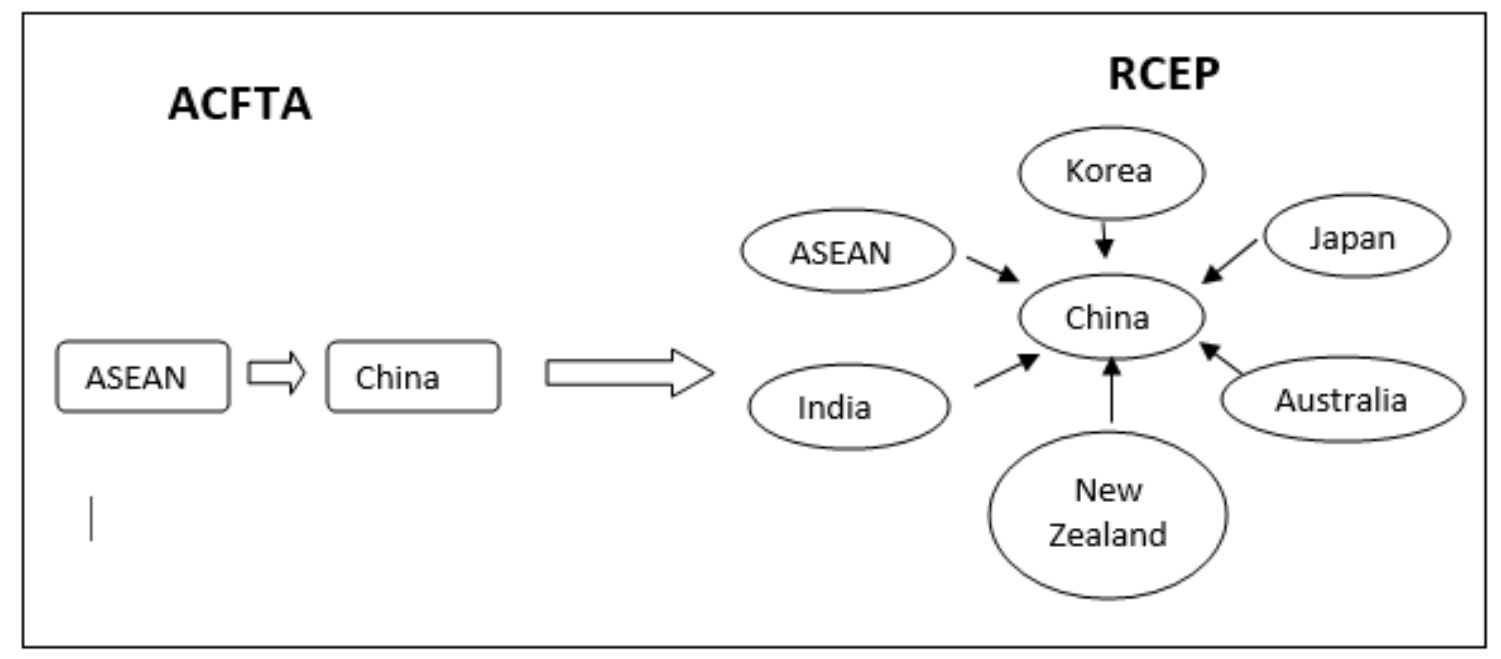

Source: Illustration by author

The easing of RCEP member states to comply with ROO will be enjoyed by many member countries that produce and export manufactured products that require a long supply chain. Countries that still depend on commodity-based exports of natural resources will get minimal benefit from the establishment of RCEP. Other threats that need to be considered by the other member countries of ASEAN is export preferential erosion. RCEP will lead to preferences that had been enjoyed by the member countries of ASEAN in the partner countries will also be enjoyed by the other ASEAN partner countries. Figure 4 shows the preferences of ASEAN 
products in China were acquired through ACFTA will be reduced because other ASEAN partner countries will also get preference in China through RCEP. For example, Indonesian exports that previously obtained the preferential rate of China will compete with Australia, India, Japan, Korea, and New Zealand in the Chinese market with the same level of preference. ASEAN member countries have been involved in lots of six regional free trade agreement that is ATIGA, AANZFTA, ACFTA, AIFTA, AJCEP, and AKFTA. In each agreement has a Schedule of Commitment different because of the sensitivity of the product each ASEAN member country of the individual partner countries also differs. However, because the main principles RCEP is doing Single Schedule of Commitment to each member state RCEP, then in each ASEAN member country will likely be no products sacrificed in the preparation of the Single Schedule of Commitment.

\section{Figure 5 : Illustration Sacrifice Indonesia in RCEP}

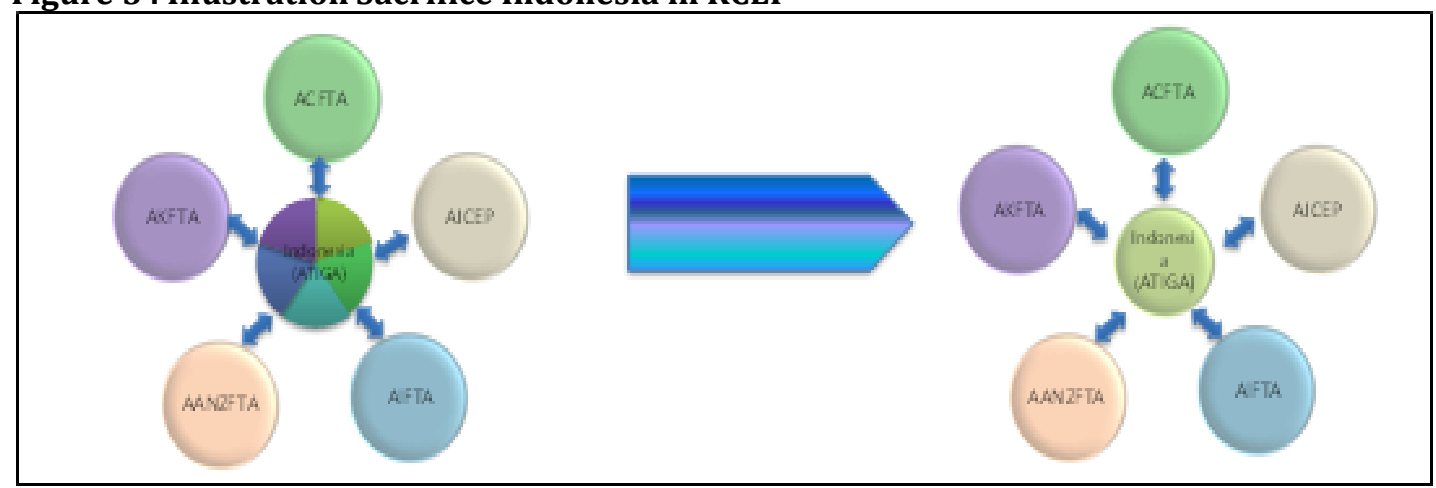

Source: Illustration author

This sacrifice will be even greater because of the commitment in RCEP expected better from ASEAN free trade agreements (ATIGA) and ASEAN + 1 (AANZFTA, ACFTA, AIFTA, AJCEP, AKFTA) were on average approximately 90\%. Figure 5 illustrates the sacrifices made by Indonesian in RCEP. The different colors indicate differences in the sensitivity of Indonesian in any free trade agreements that have been there but to meet singles Schedule of Commitment in RCEP, Indonesian must choose one color (single sensitivity). This causes many sensitive commodities are still enjoying tariff protection in the existing regional cooperation should be liberalized more quickly through RCEP.

Figure 6 : Illustration Position Negotiations Partner Country in RCEP

\begin{tabular}{c}
\hline Chlds \\
\hline 1 \\
\hline 1 \\
\hline 6 \\
\hline 0 \\
\hline 1 \\
\hline 1 \\
\hline$G$ \\
\hline
\end{tabular}

\begin{tabular}{|c|}
\hline toda \\
\hline$d$ \\
\hline 1 \\
\hline$C$ \\
\hline 1 \\
\hline 1 \\
\hline I \\
\hline 6 \\
\hline
\end{tabular}

\begin{tabular}{|l|}
\hline $10 \times 46$ \\
\hline 1 \\
\hline 1 \\
\hline 6 \\
\hline 0 \\
\hline 1 \\
\hline 1 \\
\hline 6 \\
\hline
\end{tabular}

Offer List Asean partners in ASEAN+1

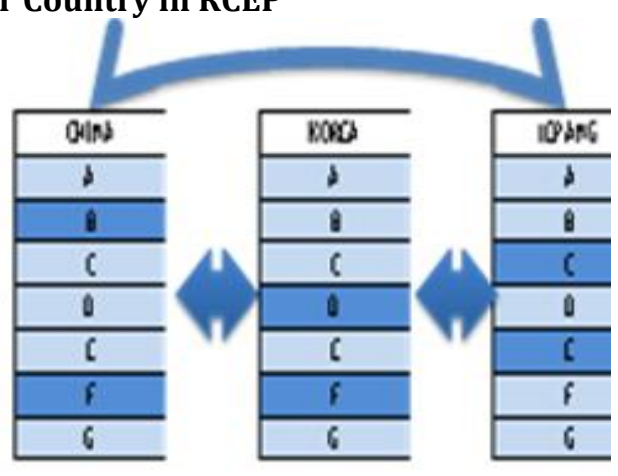

Position ASEAN partners in RCEP

Source: Illustration by author

Potential Impact on Market Expansion: Basically RCEP not at an increase in new markets in the region for the member countries of ASEAN. The new markets are created only occur between ASEAN partner countries (Australia, China, India, Japan, Korea, and New Zealand). However, the competition between the partner country the potential to provide new market access for ASEAN. Figure 6 illustrates the position negotiator in the partner countries RCEP represented by the three partner countries. Assumed all commodities contracted 
grouped into seven major groups (A to G). The dark blue color depicts the sensitive products category while the light blue color depicts products liberalized. In the picture to the left is assumed modalities countries China, Japan, and Korea in their respective regional cooperation with ASEAN (ACFTA, AKFTA, AJCEP). Because these countries feel the competition among them is heavier than the ASEAN countries, these countries have changed the categories of products in RCEP be like in the picture to the left. The impact of these changes, ASEAN will gain additional market access of the partner country. For example, in the ACFTA, product group F and $\mathrm{G}$ in the category of sensitive by China. In RCEP, China liberalizes product and make sensitive G product $B$ in RCEP. ASEAN will gain additional market access G products in China through RCEP however, can not take advantage of market access to products and through RCEP. Each partner country will gain access to new markets from other partner countries in proportion to the liberalization conducted between partner countries.

However, if the partner countries that do offer their products in RCEP as they do in regional free trade agreements with ASEAN, ASEAN will not get additional market access at all in RCEP as illustrated in Figure 6. However, if the partner countries that do offer their products in RCEP as they do in regional free trade agreements with ASEAN, ASEAN will not get additional market access at all in RCEP as illustrated in Figure 6. Negotiating position of ASEAN member countries, in general, is much weaker compared to the AFP. Figure 7 shows the simulated negotiations ASEAN member countries in RCEP (Indonesia for example). Position offer Indonesia in the ACFTA, AKFTA, and AJCEP, as shown in Figure 7, left. To meet the single list in the RCEP, assumed the position as Indonesia did offer Indonesia in AJCEP. By choosing the modalities of the AJCEP, then Indonesia will accelerate the liberalization of commodity and commodity ACFTA D in An in AKFTA. This happens because of the sensitivity of the member countries of ASEAN cooperation in each ASEAN + 1 is different, so the products are carried liberalization will also be different for each partnership.

Figure 7: Negotiations Simulation ASEAN Member Countries in RCEP

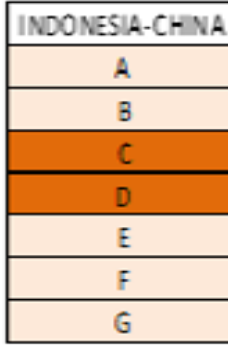

Offer List Indonesia in ASEAN+1
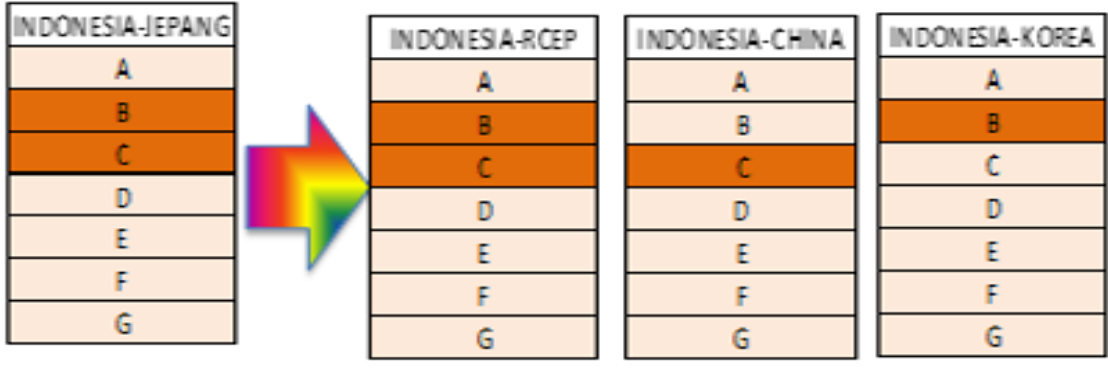

Indonesia's position after RCEP Fetr

Source: Illustration by author

Tier Mechanism to Request and Offer: The discussions in Working Group on Trade in Goods (WG-TIG) is still focused on the discussion of the request and offer. As shown in Figure 1, the new market access in RCEP only is obtained by the respective partner countries of ASEAN in other ASEAN partner countries. This led to negotiations RCEP is basically negotiating partner among ASEAN countries. Because among several partner countries do not have free trade agreements, negotiations become insidious. To accelerate the negotiations, it was agreed on the Basic Concept of the Initial Offer (BCIO). BCIO contains among others: (i) liberalization of the target is $85 \%$, and (ii) partner countries obtain facilities in developing products that will be liberalized in RCEP through 3 tier, namely: tier 1 is the most liberal and aimed for ASEAN countries, o Tier 2 less liberal and aimed at fellow partner countries who have had a bilateral trade agreement, and o Tier 3 most conservative and geared to fellow partner countries that do not have free-trade agreements.

Indonesian has expressed its objections since the tier mechanism applies only to ASEAN countries, while partners have to deliver Single Schedule of Commitment. With Single Schedule of Commitment, ASEAN must be accelerated liberalization of the category of sensitive products in the existing regional trade cooperation. In addition, the presence tier mechanism is not in accordance with the Principles agreed the time of negotiations RCEP formation and inhibit increased trade intro RCEP member countries. The biggest benefit of RCEP is the ease of access to raw materials in order to fulfill the RVC. Tier mechanism causing these benefits leak 
can optimally be utilized by ASEAN. Figure 8 illustrates two possible positions of Indonesian in the supply chain of goods in RCEP.

Figure 8: Positions of Indonesian in the Supply Chain of Goods in RCEP

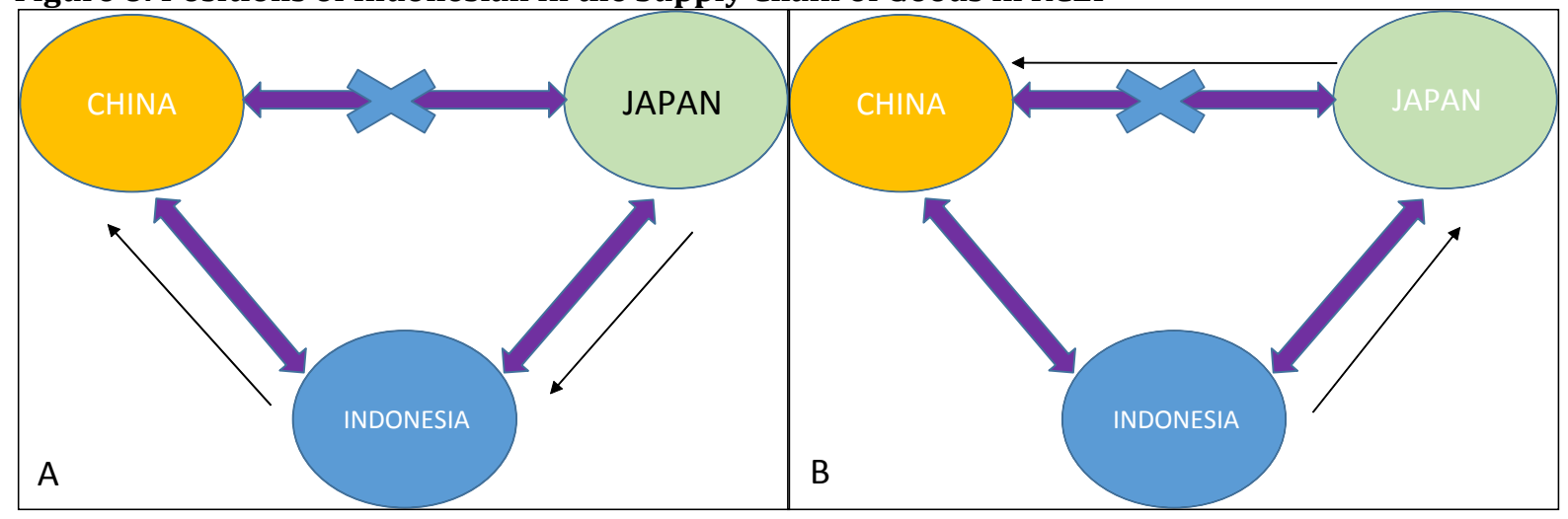

Source: Illustration by author

The existence tier mechanism could lead to China's commitment to Japan is different from China's commitment to the ASEAN member countries (eg in Indonesia). If for example, China does not open vehicle products motor with Japan but opening the product in Indonesia, then the chances of that happening are as follows:

- In figure A, Japan to export products in the motor vehicle knocked down condition to Indonesia and then assembled. Products car so then exported by Indonesia to China. This scenario will benefit Indonesia if Indonesia is located on the downstream side of the supply chain and allowed their cumulative biodegradable motor vehicle imported from Japan Indonesia with the added value that occurred in Indonesia.

- In figure B, if Indonesia became a supplier of automotive components for the motor vehicle industry in Japan, then Indonesia will not get any additional demand from Japan for the Japanese market access to China for a motor vehicle closed.

Position Offer a List of the Member States of ASEAN and Partner Countries: The partner countries, in general, has given an initial offer to ASEAN in tier 1 according to the provisions BCIO, but because the offer list given to ASEAN countries is still below the level of liberalization in trade cooperation, ASEAN + 1, virtually no additional market access to ASEAN countries in the listed product delivered in tier 1. the additional opening of market access by the ASEAN partner countries are as follows: (i) RRT just add three (3) categories of tariff heading SL / HSL in the ACFTA; (ii) India only add two (2) categories of tariff heading SL/HSL in AIFTA; (iii) Japan only add 28 categories of tariff heading SL / HSL in AJCEP; (iv) Korea did not add any of their commitment to AKFTA. Because the entire postal rates in Australia and New Zealand AANZFTA will be 0\% by 2020, Additional tariff lines two partner countries are deemed insignificant impact on ASEAN. Another thing that makes the concern is the opening of market access sensitive products trade cooperation partner countries in ASEAN + 1 to the other partner countries, but not given to ASEAN. In addition, some countries expressed partners offer list is not transparent, making it difficult to study the ASEAN countries offer their list. Some partner countries only submit a list of tariff lines and modalities reduction tariffs but not willing to give the book a complete classification. While India conveyed offer lists in Microsoft Word format, making it hard to do the analysis.

Rules of Origin: Sub-Working Group on Rules of Origin (SWG-ROO) meeting takes place very slowly. ROO is the most crucial issue in the discussion of trade in goods since it determines how a product can be recognized as coming from member countries and can take advantage of the preferential tariff. Some of the major issues of ROO is the origin criteria, accumulation, and Operational Certification procedures (OCP). The main issue in the origin criteria, namely the determination of error a product, whether a party RCEP origin or origin. RCEP origin is the recognition of a product as a result of joint production RCEP member countries. RCEP origin allows their full cumulation namely that all the value added at each level of the supply chain that occurs in member countries can be taken into account in calculating the RVC without substantial transformation and 
minimize. This will benefit the country intermediaries who only perform minimal production processes such as packaging and labeling, but remain eligible to take advantage of preferential tariffs in other member states. Full cumulation many proposed by developed country partners such as Japan, Australia, and New Zealand. Indonesia does not support the full accumulation and suggested the use of diagonal cumulation accumulation that can only be done if they fulfill the substantial transformation as used in trade cooperation, ASEAN +1 .

Another issue related to the origin criteria, namely the provisions laid down on the product specific rules (PSR). PSR is the origin criteria applied uniquely to each product in a classification Harmonized System (HS) at the six-digit level (sub-headings). Origin criteria in PSR are generally divided into three groups: Wholly Obtained (WO), Regional Value Content (RVC), and Change in tariff Classification (CTC) under the following conditions:

- WO: origin criteria are given to products that are taken directly from nature, waste products of consumption and production, as well as products made solely from WO product in a country member.

- RVC: the determination of origin criteria is done by taking into account value added occurring in the member countries.

- CTC: a product is considered to meet the criteria of origin when the non-originating component has undergone changes in the classification of the Harmonized System (HS) at a certain level.

At the meeting of the 12th RCEP in Perth, from 5,205 sub-headings, the new ASEAN agree on as much as 2,676 sub-headings (51\%). Discussion PSR itself is only carried out on 421 sub-headings that have a common position between RCEP most Participating Countries (RPCs). Although the meeting has not resulted in an agreement in the discussion of the PSR, the meeting agreed to seek to minimize the difference in the position of PSR and the justification for these differences in the next negotiations in Auckland. Indonesia suggested that not too much use of CTC with the following considerations: (i) the majority of manufactured products has fundamentally changed the classification of the initial conditions, and (ii) enables the process minimal in production processes such as assembly, forging, drawing, and rolling, and mixing so that: use of CTC does not encourage increased investment and detrimental to producers of raw materials. In the context of the de minimus, the conditions governing the minimum limit of components or non-originating materials that do not change the classification of the Harmonized System (HS) at a certain level (do not undergo substantial transformation). Demonisms in ASEAN trades cooperation in general by $10 \%$. An important issue under discussion is whether or not the origin criteria minimize if a product is WO.

Japan and India proposed a mechanism of self-certification and Korea proposed a similar mechanism called approved exporter. Self-certification/approved exporter that is the mechanism that allows the issuance of Certificates of Origin (COO) is done by the exporter in the exporting member countries. $\mathrm{COO}$ is the accompanying documents stating that export products exported goods meet the origin criteria. The use of the mechanism of self-certification/approved exporter can only be approved if it does detailed data exchange and transparency among member states. In the absence of detailed data exchange and transparency, the use of this mechanism could potentially give rise to abuse of COO. In SWG-ROO, Australia filed a Post-importation issue preferential tariff on the pretext of protecting small and medium enterprises that when exports did not understand the procedures for the use of the SKA. This mechanism allows the importer to make a claim against the preferential tariff within a certain period after the import process is complete. However, Indonesia advised being careful with the proposal because this mechanism can be used as a tool to adjust the income tax expense in the current year, the amount of administrative burden will be borne by the tax officials and customs officials and temporary suspension of preferential treatment. India also proposed granting member states can suspend preferential tariffs when exporting to member countries exporting member countries do persistent failure. However, India does not provide criteria for persistent failure so that the proposal could cause wearing member states act arbitrarily to the other Member States.

\section{Conclusion and Recommendations}

Based on this study it can be concluded that the unification of the 16 countries in the RCEP expected to reduce the spaghetti bowl effect caused by a number of free trade agreements followed by a country. However, because RCEP does not eliminate regional free trade agreements that exist, RCEP tend to add to the chain's new spaghetti bowl. In addition, the opening of market access among partner countries in the ASEAN- 
expected results in increased trade intra-ASEAN partner countries so that the impact on economic growth in the region in general and ASEAN in particular. Based on the results of negotiations in the working group found a few things, namely: (i) the potential threats that need to be considered by the member countries of ASEAN, namely the reduction in product preferences in partner countries of ASEAN (export preferential erosion). RCEP will lead to preferences that had been enjoyed by the member countries of ASEAN in the partner countries will also be enjoyed by the other ASEAN partner countries. (Ii) RCEP basically no impact on their gain new markets in the region for the member countries of ASEAN. The new markets are created only occur between ASEAN partner countries (Australia, China, India, Japan, Korea, and New Zealand). Nevertheless, the competition between the partner country the potential to provide new market access for ASEAN. Based on these findings, in order RCEP provide optimum benefit to the member countries of ASEAN, it is recommended that some of the following: The need for further studies to determine how much the level of trade openness in the RCEP, so RCEP will have maximum impact on each member country. This level of transparency will have to be mutually agreed among member states RCEP.

\section{References}

Çelikkol, Ö. O. (2013). The Implications of new age FTAs in the Asia-Pacific: TPP and RCEP, Ankara, Turki: Uluslararası Ekonomik Sorunlar, T.C. Dışişleri Bakanlığı Balgat, 59-69.

Chiang, M. H. (2013). The Potential of China-Japan-South Korea Free Trade Agreement. East Asia, 30(3), 199216.

Devadason, E. S. (2014). Framing China-Malaysia Trade Relations Beyond Asian: Factoring The Regional Comprehensive Economic Partnership, Proceedings of the Australian Academy of Business and Social Sciences Conference 2014 (in partnership with The Journal of Developing Areas).

Ezaki, M. \& Nguyen, T. D. (2008). Regional Economic Integration and Its Impacts on Growth, Income Distribution and Poverty in East Asia: A CGE Analysis, Discussion Paper No. 167, Graduate School of International Nagoya University.

Fukunaga, Y. \& Isono, Y. (2013). Taking ASEAN+1 FTAs towards the RCEP: A Mapping Study Taking ASEAN+1 FTAs towards the RCEP: A Mapping Study, ERIA Discussion Paper Series, ERIA-DP-2013-02 ERIA-DP2013-02.

Heagney, K. J. (2013). The RCEP (Regional Comprehensive Economic Partnership) and The Possible Impact of the RCEP on Lao PDR, ASEAN Economic Cooperation Division Foreign Trade Policy Department Ministry of Industry and Commerce Lao PDR.

Itakura, K. (2013). Impact of Liberalization and Improved Connectivity and Facilitation in ASEAN for the ASEAN Economic Community, ERIA Discussion Paper.

Kawai, M. \& Wignaraja, G. (2013a). Patterns of Free Trade Areas in Asia, Policy Studies, 65, Institute of Southeast Asian Studies, 30 Heng Mui Keng Terrace, Pasir Panjang Road, Singapore 119614.

Kawai, M. \& Wignaraja, G. (2013b). Policy challenges posed by Asian FTAs, Centre for Economic Policy Research (CEPR), London.

Menon, J. (2013). Can FTAs Support the Growth or Spread of International Production Networks in Asia? Australian National University Working Paper No. 2013/06.

Pomfret, R. \& Pontines, V. (2013). Exchange rate policy and regional trade agreements, in Centre for Economic Policy Research (CEPR), London.

Syadullah, M. \& Hakim, A. (2016). Free Trade: History, Development, and Implications for Indonesia, IPB Press, Bogor 2016.

Syadullah, M. \& Ardiansyah, B. G. (2014). Regional Comprehensive Economic Partnership. The Indonesia Quarterly, 42(1). 